\title{
FAKTOR - FAKTOR YANG BERHUBUNGAN DENGAN UPAYA PENCEGAHAN KOMPLIKASI KEHAMILAN DI BPM ELLNA TAHUN 2018
}

\author{
Nen Sastri \\ Program Studi Kebidanan Sekolah Tinggi Ilmu Kesehatan Bina Husada \\ Jl. Syech Abdul Somad No.28 Kel. 22 Ilir Palembang Sumatera Selatan 30131 \\ Email: nensastri@yahoo.com
}

\section{ABSTRAK}

Menurut laporan dari WHO, kematian ibu umumnya terjadi akibat komplikasi saat, dan pasca kehamilan. Adapun jenis-jenis komplikasi yang menyebabkan mayoritas kasus kematian ibu sekitar $75 \%$ dari total kasus kematian ibu - adalah pendarahan, infeksi, tekanan darah tinggi saat kehamilan, komplikasi persalinan, dan aborsi yang tidak aman (WHO, 2014).

Penelitian ini bertujuan untuk diketahuinya hubungan kejadian komplikasi kehamilan, umur, pendidikan, pekerjaan ibu, pekerjaan suami, abortus, jarak kelahiran, paritas, kunjungan ANC pada ibu hamil di Bidan Praktik Mandiri Ellna Palembang tahun 2018. Rancangan penelitian yang digunakan penelitian observasional dengan pendekatan case control. Populasi dalam penelitian ini adalah semua ibu hamil di Bidan Praktik Mandiri Ellna Palembang pada bulan Januari sd Desember tahun 2018. Kriteria kasus adalah semua tersangka ibu hamil dengan komplikasi kehamilan yang tercatat dalam buku register kehamilan dari bulan Januari sampai dengan Desember tahun 2018 di BPM Ellna. Kriteria kontrol adalah semua tersangka ibu hamil yang tidak komplikasi kehamilan yang tercatat dalam buku register kehamilan dari bulan Januari sampai dengan Desember tahun 2018 di BPM Ellna. Besar sampel menggunakan sampel minimal yaitu 668 ibu. analisa data yang digunakan yaitu Analisis univariat, Analisis bivariat, Analisa Multivariat.

Hasil penelitian bahwa hubungan antara usia ibu dengan komplikasi kehamilan. Hasil uji chi square, diperoleh nilai signifikan $p=0,922$. hubungan antara pendidikan ibu dengan komplikasi kehamilan. Hasil uji chi square, diperoleh nilai signifikan $p=0,960$. hubungan antara pekerjaan ibu dengan komplikasi kehamilan. Hasil uji chi square, diperoleh nilai signifikan $p=0,022$. hubungan antara pekerjaan suami dengan komplikasi kehamilan. Hasil uji chi square, diperoleh nilai signifikan $p=1,000$. hubungan antara paritas dengan komplikasi kehamilan. Hasil uji chi square, diperoleh nilai signifikan $p=0,000$. hubungan antara jarak kehamilan dengan komplikasi kehamilan. Hasil uji chi square, diperoleh nilai signifikan $p=0,777$. hubungan antara riwayat abortus dengan komplikasi kehamilan. Hasil uji chi square, diperoleh nilai signifikan $p=0,777$. hubungan antara kunjungan ANC dengan komplikasi kehamilan. Hasil uji chi square, diperoleh nilai signifikan $p=0,821$.

Simpulannya ada hubungan antara pekerjaan ibu dengan komplikasi kehamilan, ada hubungan antara paritas dengan komplikasi kehamilan, ada hubungan antara riwayat abortus dengan komplikasi kehamilan. Saran diharapkan bagi ibu hamil lebih banyak mengetahui upaya pencegahan komplikasi kehamilan.

Kata kunci: Komplikasi kehamilan, ibu hamil

\section{ABSTRACT}

According to reports from WHO, maternal deaths occur during complications, and post pregnancy. More than $75 \%$ of the total cases of maternal death - are bleeding, infection, high blood pressure during pregnancy, childbirth complications, and unsafe abortion (WHO, 2014). This research is intended to be known. Participation, complications, assessment, age, education, mother's occupation, husband's occupation, abortion, birth distance, parity, ANC visits to pregnant women at the Ellna Independent Practice Midwife, Palembang, 2018. The study design used observational research with cases such as controls. The population in this study was all pregnant women in the Independent Practice Midwife Ellna Palembang in January to December 2018. Case criteria are all contained in the pregnancy book that discusses the pregnancy register book in January to 
December 2018 at Ellna BPM. Control criteria are all pregnant woman suspects who did not experience pregnancy complications recommended in the pregnancy register book from January to December 2018 at BPM Ellna. Large sample using a minimum sample of 668 mothers. Analysis of the data used is univariate analysis, bivariate analysis, multivariate analysis.Results of research on the relationship between maternal age and pregnancy complications. Chi square test results, obtained a significant value of $p=0.922$. the relationship between maternal education and pregnancy complications. Chi square test results, obtained a significant value of $p=0.960$. the relationship between mother's work and pregnancy complications. Chi square test results, obtained a significant value of $p=0.022$. the relationship between husband's work and pregnancy complications. Chi square test results, obtained a significant value of $p=1,000$. the relationship between parity and pregnancy complications. Chi square test results, obtained a significant value of $p=0,000$. the relationship between the distance of pregnancy with pregnancy complications. Chi square test results, obtained a significant value of $p=0.777$. relationship between history of abortion with pregnancy complications. Chi square test results, obtained a significant value of $p=0.777$. the relationship between ANC visits and pregnancy participation. Chi square test results, obtained a significant value of $p=0.821$. In conclusion, there is a relationship between mothers and pregnancy complications, there is a relationship between parity and pregnancy, there is a relationship between pregnancy abortion and pregnancy complications. Expected advice for pregnant women.

Keywords: Pregnancy complications, pregnant women

\section{Pendahuluan}

Menurut laporan dari WHO, kematian ibu umumnya terjadi akibat komplikasi saat, dan pasca kehamilan. Adapun jenis-jenis komplikasi yang menyebabkan mayoritas kasus kematian ibu - sekitar $75 \%$ dari total kasus kematian ibu - adalah pendarahan, infeksi, tekanan darah tinggi saat kehamilan, komplikasi persalinan, dan aborsi yang tidak aman (WHO, 2014) (1).

Berdasarkan laporan, jumlah kasus kematian ibu di kota Palembang tahun 2017 sebanyak 7 orang kematian ibu dari 27.876 kelahiran hidup. Jumlah tersebut mengalami penurunan jika dibandingkan dengan tahun 2016 (10 kematian ibu dari 29.521 kelahiran hidup). Nilai ini masih dibawah target AKI nasional untuk RPJMN tahun 2016 sebesar 34 per 100.000 kelahiran hidup. Dari 7 kasus kematian ibu tersebut, penyebab kematian terbanyak adalah hipertensi dalam kehamilan
$72 \%$ (5 orang), perdarahan 14\% (1 orang), gangguan metabolik (DM) sebanyak 1 orang (Profil Seksi Kesehatan Keluarga Gizi dan Masyarakat Palembang, 2017) (2).

Pelayanan kesehatan ibu hamil di dapatkan bahwa cakupan kunjungan $\mathrm{K} 1$ pada ibu hamil tahun 2017 sebesar 99,96\% (29.598/29.610) nilai cakupan tersebut meningkat dibanding cakupan tahun 2016 (98,5\%). Tahun 2017 cakupan kunjungan K4 kota Palembang sebesar 99,0 \% (29.305/29.610) cakupan tersebut mengalami peningkatan dibandingkan tahun 2016 sebesar $96,0 \%{ }^{(2)}$

Komplikasi kebidanan yang ditangani adalah cakupan ibu dengan komplikasi kebidanan yang ditangani sesuai standar pelayanan oleh tenaga yang berkompeten. ntuk tingkat kota Palembang tahun 2017 cakupan komplikasi kebidanan yang 
ditangani sebesar 92,5\% (5.477/5.922). Angka cakupan ini sudah mencapai target kota Palembang (80\%). Cakupan ini tidak mengalami perubahan jika dibandingkan tahun 2016sebesar 92,5\%. 10 jenis komplikasi kebidanan terbanyak di kota Palembang tahun 2017 yaitu bumil dengan LILA $<23,5 \mathrm{~cm}$, bumil dengan anemia $(\mathrm{Hb}<$ 11 gr\%), perdarahan pervaginam, kelainan letak janin, ketuban pecah dini, HDK (TD > 140 ,> 90 mmHg, kelainan jumlah janin, distosia, kelainan besar janin, dan lain-lain (2).

Berdasarkan penelitian yang dilakukan oleh Murdiati Ari, Jati Patria Sutopo (2017) dengan judul Analisis Faktor- Faktor Yang Berhubungan Dengan Perilaku Ibu Hamil Dalam Merencanakan Persalinan Untuk Pencegahan Komplikasi di Wilayah Kerja Puskesmas Bandar Harjo Semarang, Hasil: variabel yang paling dominan berpengaruh adalah dukungan suami $(\mathrm{OR}=7,037)$. Hal ini berarti bahwa dukungan suami dalam program perencanaan persalinan yang baik memungkinkan ibu hamil memiliki perencanaan persalinan yang baik 7,07 kali dibandingkan dengan dukungan suami yang kurang ${ }^{(3)}$.

Berdasarkan penelitian yang dilakukan oleh Nasriyah, Tristanti Ika (2017) dengan judul Upaya Pencegahan Komplikasi Kehamilan Dan Persalinan Berdasarkan Karakteristik lbu Hamil di Kabupaten Kudus. Hasil: berdasarkan uji statistik menggunakan uji kendall Tau d dapatkan hasil bahwa $P$ value 0,010 . Nilai $P$ value $<0,05$ berarti ada hubungan antara pengetahuan dengan pelaksanaan upaya P4K (Perencanaan, Persalinan dan Pencegahan Komplikasi) (4).

Berdasarkan penelitian yang dilakukan oleh Werdiyanti, Mulyadi, Karundeng Michael (2017) dengan judul Hubungan Penerapan Program Perencanaan Persalinan dan Pencegahan Komplikasi Kehamilan oleh Ibu Hamil Dengan Komplikasi Kehamilan di Puskesmas Doloduo Kab. Bolaang Mongondow. Hasil: uji chi square diperoleh nilai signifikan $P=0,000<0,05$. Hal ini menunjukkan bahwa terdapat hubungan antara penerapan program perencanaan persalinan dan pencegahan komplikasi oleh iu hamil (P4K) dengan komplikasi kehamilan di puskesmas Duloduo Kab. Bolaang Mongondow ${ }^{(5)}$.

Menurut data rekam medik yang diperoleh dari Bidan Praktik Mandiri Ellna pada tahun 2015 ibu yang melakukan pemeriksaan kehamilan sebanyak 1.732 ibu dan yang mengalami komplikasi kehamilan sebanyak 12 ibu, pada tahun 2016 ibu yang melakukan pemeriksaan kehamilan sebanyak 1.550 ibu dan yang komplikasi kehamilan sebanyak 15 ibu dan pada tahun 2017 ibu yang melakukan pemeriksaan kehamilan sebanyak 1.620 dan ibu yang mengalami komplikasi kehamilan sebanyak 10 ibu ( Data BPM Ellna, 2017) ${ }^{(6) .}$

Berdasarkan latar belakang diatas maka penulis tertarik untuk melakukan penelitian tentang "Faktor - Faktor Yang Berhubungan Dengan Upaya Pencegahan Komplikasi Kehamilan di BPM Ellna Tahun 2018". 


\section{METODE PENELITIAN}

\section{Desain Penelitian}

Rancangan penelitian yang digunakan penelitian observasional dengan pendekatan case control.

\section{Lokasi Penelitian}

Jalan Ali Gatmir 11 llir no. 105 RT.04 RW.01 Palembang.

\section{Populasi dan Sampel}

Populasi dalam penelitian ini adalah semua ibu hamil di Bidan Praktik Mandiri Ellna Palembang pada bulan Januari sd Desember tahun 2018.

Kriteria Kasus adalah semua tersangka ibu hamil dengan Komplikasi kehamilan yang tercatat dalam buku register kehamilan dari bulan Januari sampai dengan Desember tahun 2018 dan bertempat tinggal di wilayah urban.

Kriteria Kontrol adalah semua tersangka ibu hamil yang tidak komplikasi kehamilan yang tercatat dalam buku register kehamilan dari bulan Januari sampai dengan Desember tahun 2018 dan bertempat tinggal diwilayah urban.

\section{Teknik pengumpulan data}

Data sekunder adalah data yang didapat tidak secara langsung dari objek penelitian (Arikunto, Suharsimi, 2010) ${ }^{(7)}$.

Data yang dikumpulkan merupakan data sekunder yang diperoleh melalui observasi rekam medik pasien ibu hamil dengan komplikasi kehamilan dari bulan Januari sampai dengan bulan Desember di BPM Ellna Tahun 2018.

Teknik Analisa Data a. Analisis univariat

Digunakan untuk menggambarkan variabel-variabel deskriptif seperti umur, pendidikan, pekerjaan, jarak kelahiran, paritas, riwayat abortus, kunjungan ANC dengan komplikasi kehamilan di Bidan Praktik Mandiri Ellna Palembang.

b. Analisis bivariat

Untuk melihat hubungan masing-masing variabel independen terhadap variable dependent dengan menggunakan uji ChiSquare nilai a 0,05 untuk menganalisis hubungan antara variabel independen (umur, pendidikan, pekerjaan, jarak kelahiran, paritas, riwayat abortus, kunjungan ANC) dengan komplikasi kehamilan jika $p$ value $\leq 0,05$ maka hasil perhitungan secara statistik bermakna jika $p$ value $>0,05$ maka hasil perhitungan statistik tidak bermakna.

c. Analisa Multivariat

Pada analisa multivariat peneliti menggunakan uji statistik regresi logistik karena metoda ini dianggap cocok untuk menjelaskan penelitian dengan variabel dependen ( $Y$ ) numerik dan variabel independen $(X)$ maupun katagorik, melalui beberapa langkah sampai pada model hasil akhir.

\section{HASIL PENELITIAN}

\section{Analisa Univariat}

Analisis univariat untuk mengetahui jumlah dan persentase dari masing-masing variabel-variabel. Variabel independen terdiri 
dari usia, pendidikan, pekerjaan, jarak kelahiran, paritas, riwayat abortus, kunjungan ANC sedangkan variabel dependen yaitu komplikasi kehamilan. Hasil analisis deskriptif disajikan pada gambar sebagai berikut:

1. Distribusi Frekuensi Berdasarkan Usia Hasil analisis distribusi frekuensi berdasarkan usia didapatkan bahwa dari 668 responden rentang usia paling banyak ditemukan yaitu usia $20-<35$ tahun sebanyak 538 orang $(80,5 \%)$ sedangkan pada usia beresiko (<20->35 tahun) yaitu 130 orang (19,5\%). Hasil analisis disajikan pada gambar.1

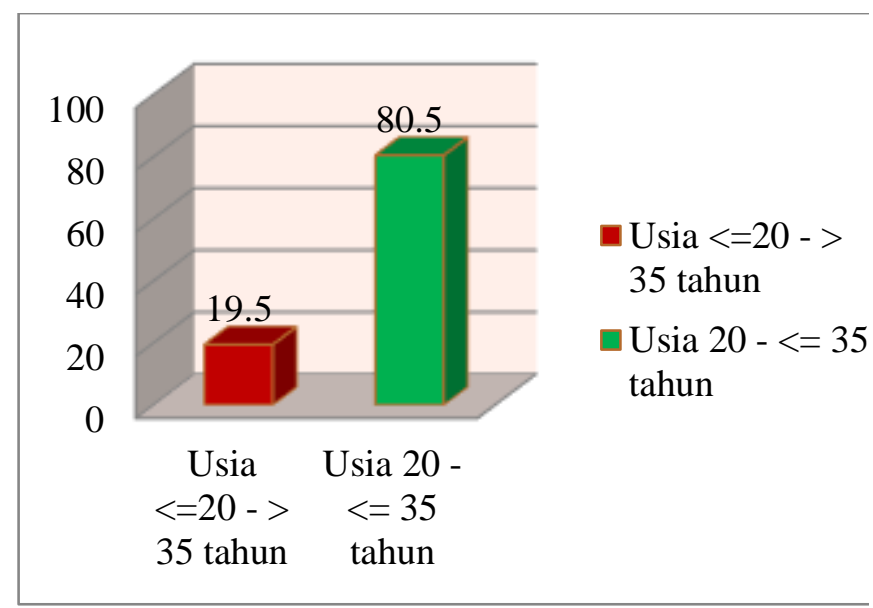

\section{Gambar 1. Distribusi Berdasarkan Usia}

\section{Distribusi Frekuensi Berdasarkan}

\section{Pendidikan Ibu}

Hasil analisis distribusi frekuensi berdasarkan pendidikan Ibu didapatkan bahwa dari 668 responden pendidikan Ibu yang rendah (SDSMP) sebanyak 174 orang (26\%) sedangkan Ibu yang mempunyai pendidikan tinggi $\geq S M A$ yaitu 494 orang (74\%). Hasil analisis disajikan pada gambar.2

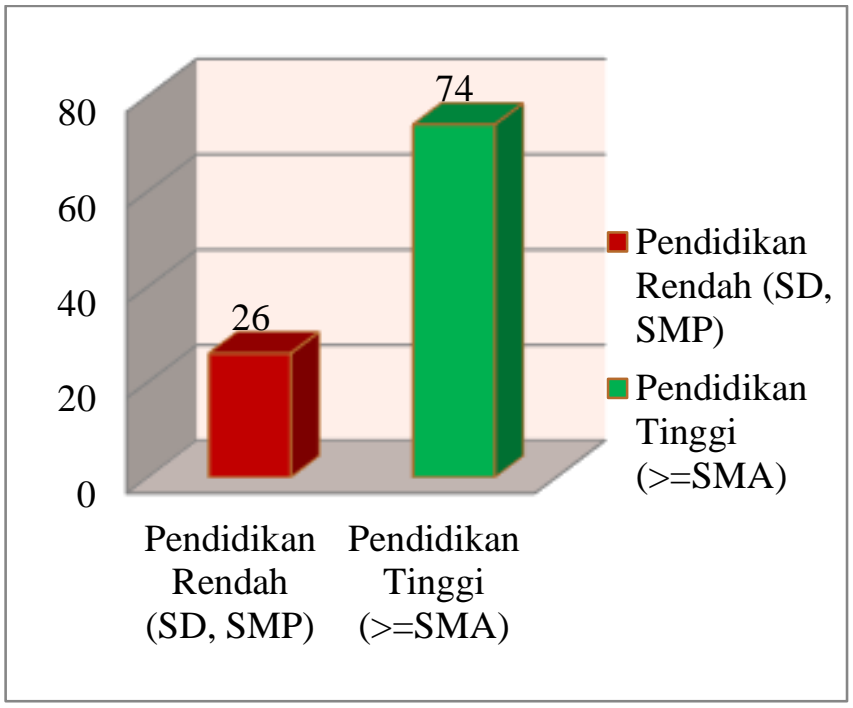

\section{Gambar 2 Distribusi Berdasarkan Pendidikan lbu}

\section{Distribusi Frekuensi Berdasarkan}

\section{Pekerjaan Ibu}

Hasil analisis distribusi frekuensi berdasarkan pekerjaan lbu didapatkan bahwa dari 668 responden lbu yang tidak sebanyak 509 orang $(76,2 \%)$ lebih banyak dibandingkan dengan Ibu yang bekerja yaitu 159 orang $(23,8 \%)$. Hasil analisis disajikan pada gambar.3

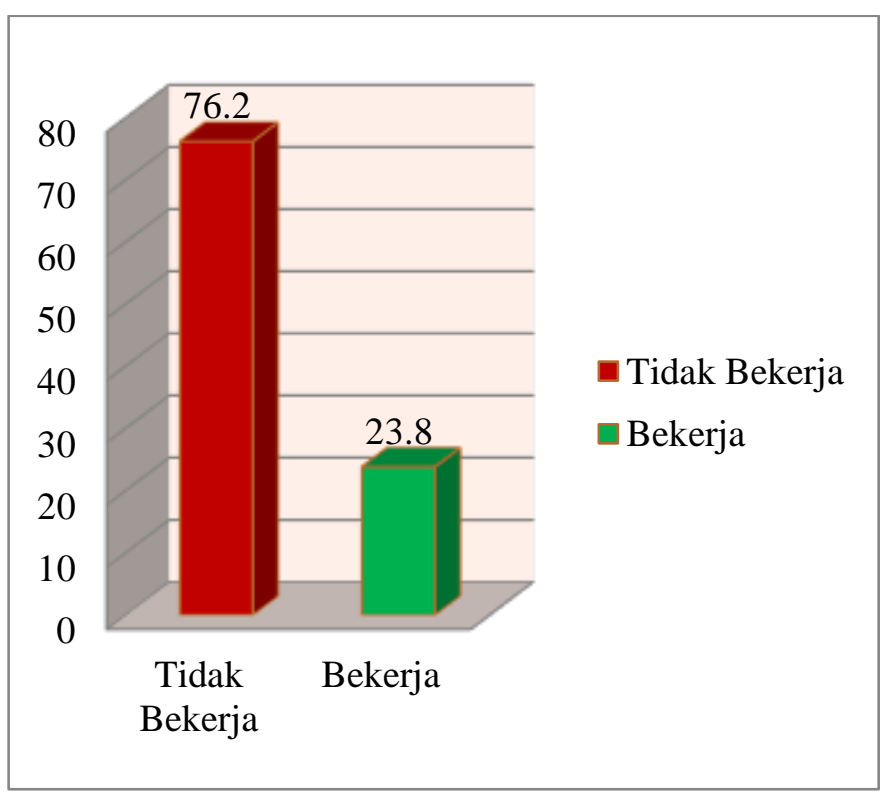


Gambar 3. Distribusi Berdasarkan Pekerjaan Ibu

\section{Distribusi Frekuensi Berdasarkan \\ Pekerjaan suami}

Hasil analisis distribusi frekuensi berdasarkan pekerjaan suami didapatkan bahwa dari 668 responden suami yang bekerja sebanyak 664 orang $(99,4 \%)$ sedangkan suami yang tidak hanya sedangkan sebanyak 4 orang $(0,6 \%)$. Hasil analisis disajikan pada gambar.4

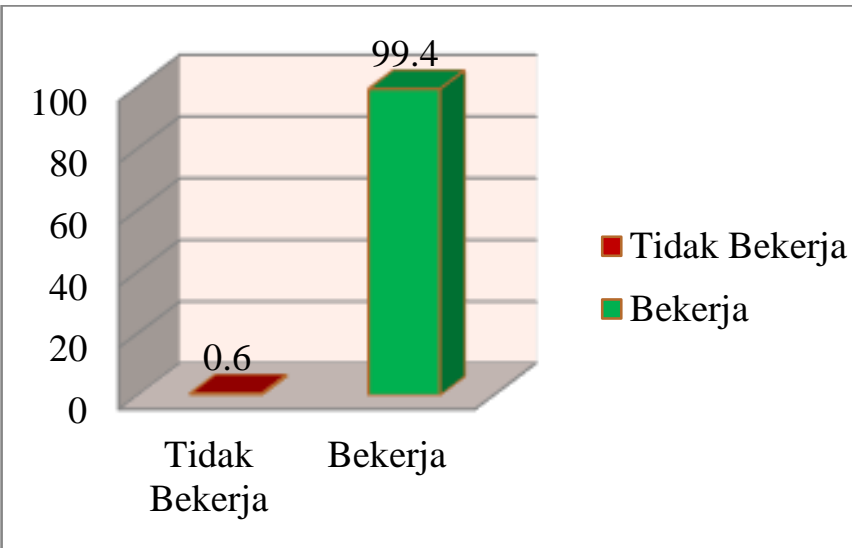

\section{Gambar 4. Distribusi Berdasarkan}

\section{Pekerjaan suami}

\section{Distribusi Frekuensi Berdasarkan \\ Paritas}

Hasil analisis distribusi frekuensi berdasarkan paritas didapatkan bahwa dari 668 responden paritas dengan resiko tinggi sebanyak 95 orang $(14,2 \%)$ sedangkan ayah paritas dengan resiko rendah sebanyak 573 orang (85,8\%). Hasil analisis disajikan pada gambar.5

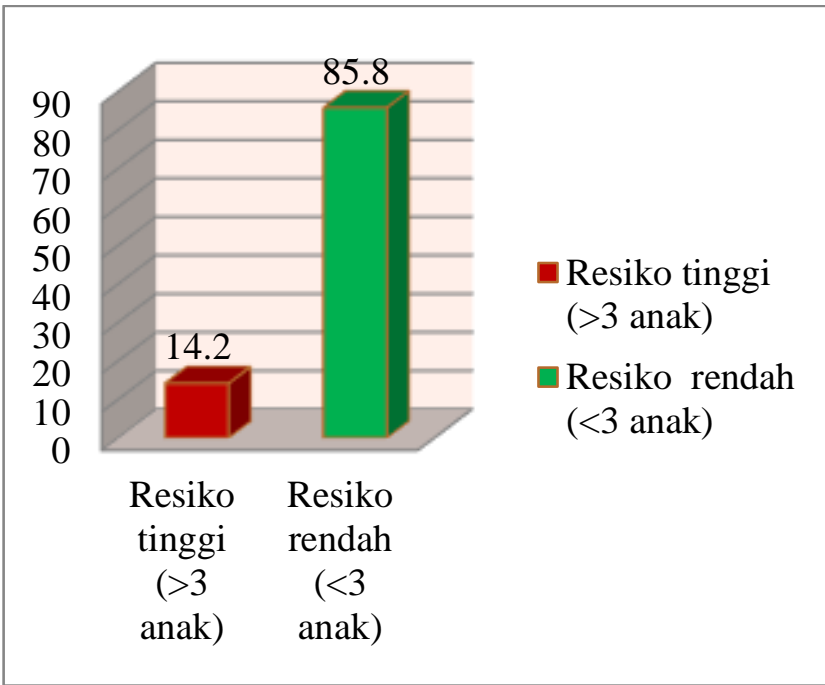

Gambar 5. Distribusi Berdasarkan Paritas

6. Distribusi Frekuensi Berdasarkan Jarak

\section{Kehamilan}

Hasil analisis distribusi frekuensi berdasarkan jarak kehamilan didapatkan bahwa dari 668 responden paritas dengan resiko tinggi (>2 tahun) sebanyak 75 orang $(11,2 \%)$ sedangkan jarak kehamilan dengan resiko rendah (2-4 tahun) sebanyak 593 orang $(88,8 \%)$. Hasil analisis disajikan pada gambar.6

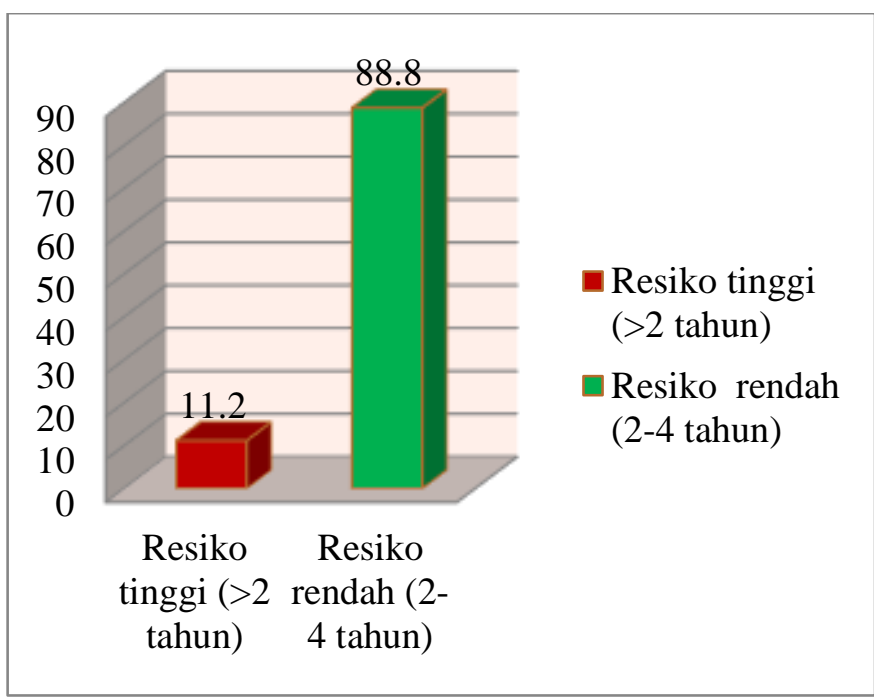

Gambar 6. Distribusi Berdasarkan Jarak Kehamilan 


\section{Distribusi Frekuensi Berdasarkan Kunjungan ANC}

Hasil analisis distribusi frekuensi berdasarkan kunjungan ANC didapatkan bahwa dari 668 responden kunjungan ANC dengan resiko tinggi ( $<4$ kali) sebanyak 520 orang $(77,8 \%)$ lebih banyak ditemukan dibandingkan kunjungan ANC dengan resiko rendah ( $\geq 4$ kali) sebanyak 148 orang (22,2\%). Hasil analisis disajikan pada gambar.7

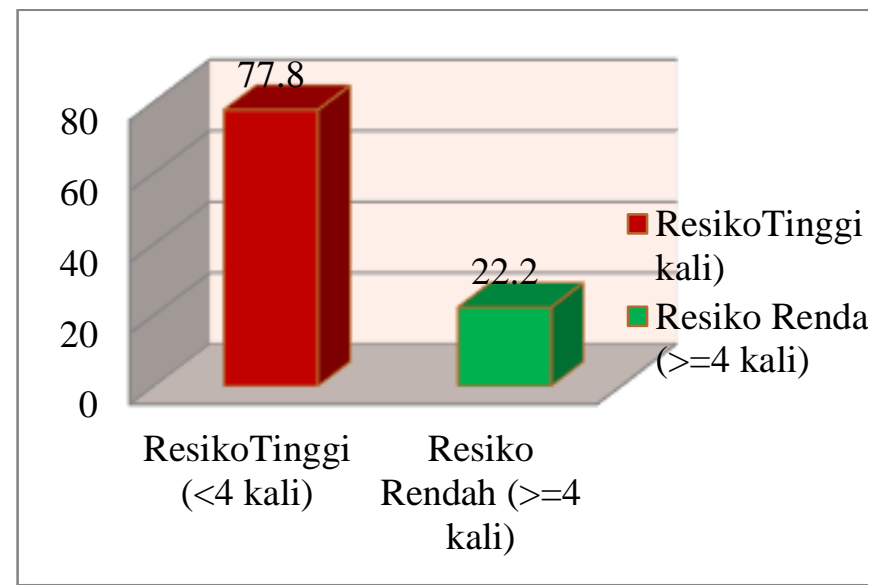

\section{Gambar 7. Distribusi Berdasarkan}

\section{Kunjungan ANC}

\section{Distribusi Frekuensi Berdasarkan}

\section{Riwayat}

\section{Abortus}

Hasil analisis distribusi frekuensi berdasarkan riwayat abortus didapatkan bahwa dari 668 responden lbu dengan riwayat abortus sebanyak 63 orang $(9,4 \%)$ sedangkan lbu yang tidak pernah mempunyai riwayat abortus sebanyak 605 orang $(90,6 \%)$. Hasil analisis disajikan pada gambar.8

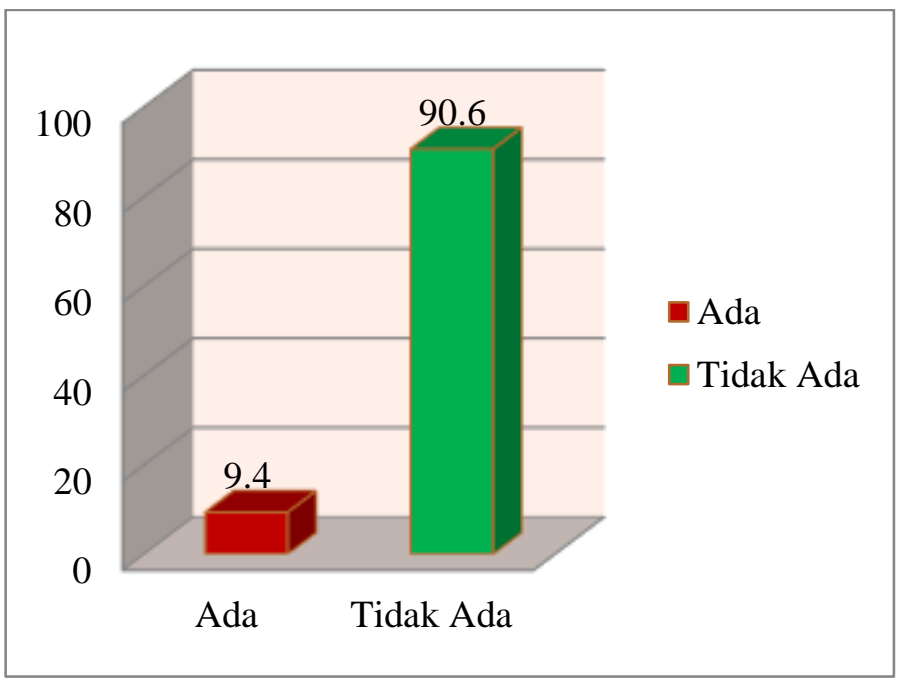

Gambar 8.Distribusi Berdasarkan Riwayat Abortus

\section{Distribusi Frekuensi Berdasarkan}

\section{Komplikasi Kahamilan}

Hasil analisis distribusi frekuensi berdasarkan komplikasi kehamilan didapatkan bahwa dari 668 responden lbu dengan komplikasi kehamilan sebanyak 78 orang $(11,7 \%)$ sedangkan Ibu yang tidak mengalami komplikasi kehamilan sebanyak 590 orang $(88,3 \%)$. Hasil analisis disajikan pada gambar.9

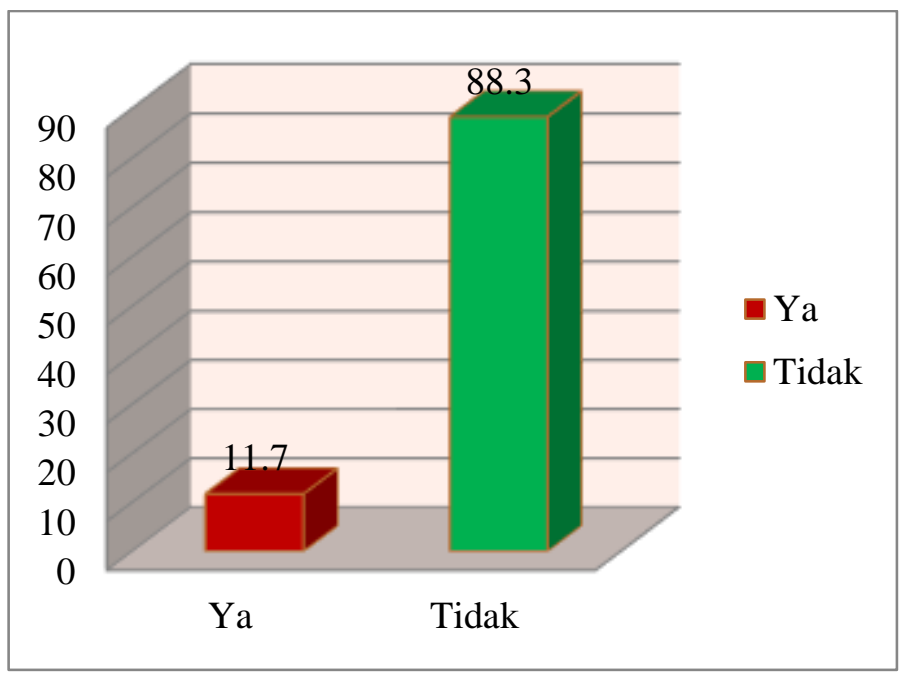

Gambar 9..Distribusi Berdasarkan Komplikasi

Kehamilan 


\section{Analisis Bivariat}

Analisis bivariat untuk melihat hubungan masing-masing variabel independen terhadap variabel dependen dengan menggunakan uji Chi-Square. Variabel independen (umur, pendidikan, pekerjaan, jarak kelahiran, paritas, riwayat abortus, kunjungan ANC) sedangkan variabel dependen yaitu komplikasi kehamilan. Hasil analisis disajikan pada tabel sebagai berikut:

\section{Hubungan Usia dengan Komplikasi Kehamilan}

Hasil analisis hubungan usia dengan komplikasi kehamilan didapatkan bahwa dari 130 lbu yang berusia resiko tinggi $(<20-\geq 35$ tahun) yang mengalami komplikasi kehamilan sebanyak 16 orang (12,3\%) sedangkan lbu yang berusia resiko rendah (20-35 tahun) sebanyak 62 orang $(11,5 \%)$ dari 538 orang. Hasil uji chi square, diperoleh nilai signifikan $\mathrm{p}=0,922(p$ value $>0,05)$. Hal ini menunjukkan bahwa Ho diterima, Ha ditolak sehingga dapat disimpulkan tidak ada hubungan antara usia ibu dengan komplikasi kehamilan.
Tabel 1. Hubungan Usia dengan

$$
\text { Komplikasi Kehamilan }
$$

\begin{tabular}{|c|c|c|c|c|c|}
\hline \multirow[t]{2}{*}{$\begin{array}{l}\text { Us } \\
\text { ia }\end{array}$} & \multicolumn{2}{|c|}{$\begin{array}{l}\text { Komplikasi } \\
\text { Kehamilan }\end{array}$} & \multirow{2}{*}{$\begin{array}{l}\text { Tot } \\
\text { al } \\
\text { n } \\
(\%)\end{array}$} & \multirow[b]{2}{*}{$\begin{array}{l}p \\
v \\
a l \\
u \\
e\end{array}$} & \multirow{2}{*}{$\begin{array}{l}\text { OR } \\
(95 \% \\
\text { CI) }\end{array}$} \\
\hline & $\begin{array}{l}\text { Ya } \\
\text { n } \\
(\%)\end{array}$ & $\begin{array}{l}\text { Tid } \\
\text { ak } \\
\text { n } \\
(\%)\end{array}$ & & & \\
\hline$<=20$ & 16 & 114 & 130 & & 1,078 \\
\hline$->35$ & $(12,3)$ & $(87,7)$ & $(100,0)$ & 0,92 & $(0,599$ \\
\hline tahun & & & & 2 & $1,937)$ \\
\hline 20 & 62 & 476 & 538 & & \\
\hline 35 & $(11,5)$ & $(88,5)$ & $(100,0$ & & \\
\hline tahun & & & ) & & \\
\hline $\begin{array}{l}\text { Tot } \\
\text { al }\end{array}$ & $\begin{array}{l}78 \\
(11,7)\end{array}$ & $\begin{array}{l}590 \\
(88,3)\end{array}$ & $\begin{array}{l}668 \\
(100,0 \\
)\end{array}$ & & \\
\hline
\end{tabular}

\section{Hubungan Pendidikan lbu dengan Komplikasi Kehamilan}

Hasil analisis hubungan pendidikan Ibu dengan komplikasi kehamilan didapatkan bahwa dari 174 lbu yang berpendidikan rendah yang mengalami komplikasi kehamilan sebanyak 21 orang (12,1\%) sedangkan lbu yang berpendidikan tinggi sebanyak 57 orang $(11,5 \%)$ dari 494 orang. Hasil uji chi square, diperoleh nilai signifikan $p=0,960$ ( $p$ value $>0,05)$. Hal ini menunjukkan bahwa $\mathrm{Ho}$ diterima, $\mathrm{Ha}$ ditolak sehingga dapat disimpulkan tidak ada hubungan antara pendidikan ibu dengan komplikasi kehamilan. 
Tabel 2. Hubungan Pendidikan Ibu dengan Komplikasi Kehamilan

\begin{tabular}{|c|c|c|c|c|c|}
\hline \multirow[t]{2}{*}{$\begin{array}{l}\text { Pendidi } \\
\text { kan Ibu }\end{array}$} & Komplikasi & $\begin{array}{l}\text { likasi } \\
\text { hilan }\end{array}$ & \multirow{2}{*}{$\begin{array}{l}\text { Total } \\
\text { n (\%) }\end{array}$} & \multirow{2}{*}{$\begin{array}{l}p \\
\text { valu } \\
e\end{array}$} & \multirow{2}{*}{$\begin{array}{l}\text { OR } \\
(95 \% \mathrm{Cl})\end{array}$} \\
\hline & $\begin{array}{l}\text { Ya } \\
\text { n } \\
(\%)\end{array}$ & $\begin{array}{l}\text { Tid } \\
\text { ak } \\
\mathbf{n} \\
\text { (\%) }\end{array}$ & & & \\
\hline Pendidi & 21 & 153 & 174 & & 1,052 \\
\hline kan & $(12,1)$ & $(87,9)$ & $(100,0)$ & 0,96 & $(0,617-$ \\
\hline rendah & & & & 0 & $1,793)$ \\
\hline Pendidi & 57 & 437 & 494 & & \\
\hline an & $(11,5)$ & $(88,5)$ & $(100,0$ & & \\
\hline tinggi & & & ) & & \\
\hline Total & 78 & 590 & 668 & & \\
\hline & $(11,7)$ & $(88,3)$ & $(100,0)$ & & \\
\hline
\end{tabular}

\section{Hubungan Pekerjaan Ibu dengan}

\section{Komplikasi Kehamilan}

Hasil analisis hubungan pekerjaan Ibu dengan komplikasi kehamilan didapatkan bahwa dari 509 lbu yang tidak bekerja yang mengalami komplikasi kehamilan sebanyak 68 orang (13,4\%) sedangkan Ibu yang bekerja sebanyak 10 orang $(6,3 \%)$ dari 159 orang. Hasil uji chi square, diperoleh nilai signifikan $p=0,022$ ( $p$ value $<0,05)$. Hal ini menunjukkan bahwa Ho ditolak, $\mathrm{Ha}$ diterima sehingga dapat disimpulkan ada hubungan antara pekerjaan ibu dengan komplikasi kehamilan.
Tabel 3. Hubungan Pekerjaan Ibu dengan Komplikasi Kehamilan

\section{Pek Komplikasi}

erja Kehamilan Total $p \quad O R$

an $\quad$ Ya Tidak $n$ valu $(95 \%$

$\begin{array}{llllll}\text { Ibu } & \mathrm{n} & \mathrm{n} & (\%) & \mathrm{e} & \mathrm{Cl})\end{array}$

(\%) (\%)

$\begin{array}{llllll}\text { Tida } & 68 & 441 & 509 & & 2,298 \\ k & (13,4) & (86,6) & (100,0) & 0,02 & (1,121- \\ \text { beke } & & & & 2 & 4,577) \\ \text { rja } & & & & & \\ \text { Beke } & 10 & 149 & 159 & & \\ \text { rja } & (6,3) & (93,7) & (100,0) & & \\ \text { Total } & 78 & 590 & 668 & & \\ & (11,7) & (88,3) & (100,0) & & \end{array}$

\section{Hubungan Pekerjaan Suami dengan} Komplikasi Kehamilan

Hasil analisis hubungan pekerjaan Suami dengan komplikasi kehamilan didapatkan bahwa dari 4 suami yang tidak bekerja yang istrinya mengalami komplikasi kehamilan sebanyak 0 orang $(0 \%)$ sedangkan suami yang bekerja sebanyak 78 orang $(11,7 \%)$ dari 664 orang. Hasil uji chi square, diperoleh nilai signifikan $p=1,000$ ( $p$ value $>0,05)$. Hal ini menunjukkan bahwa Ho diterima, Ha ditolak sehingga dapat disimpulkan tidak ada hubungan antara pekerjaan suami dengan komplikasi kehamilan. 
Tabel 4. Hubungan Pekerjaan Suami dengan Komplikasi Kehamilan

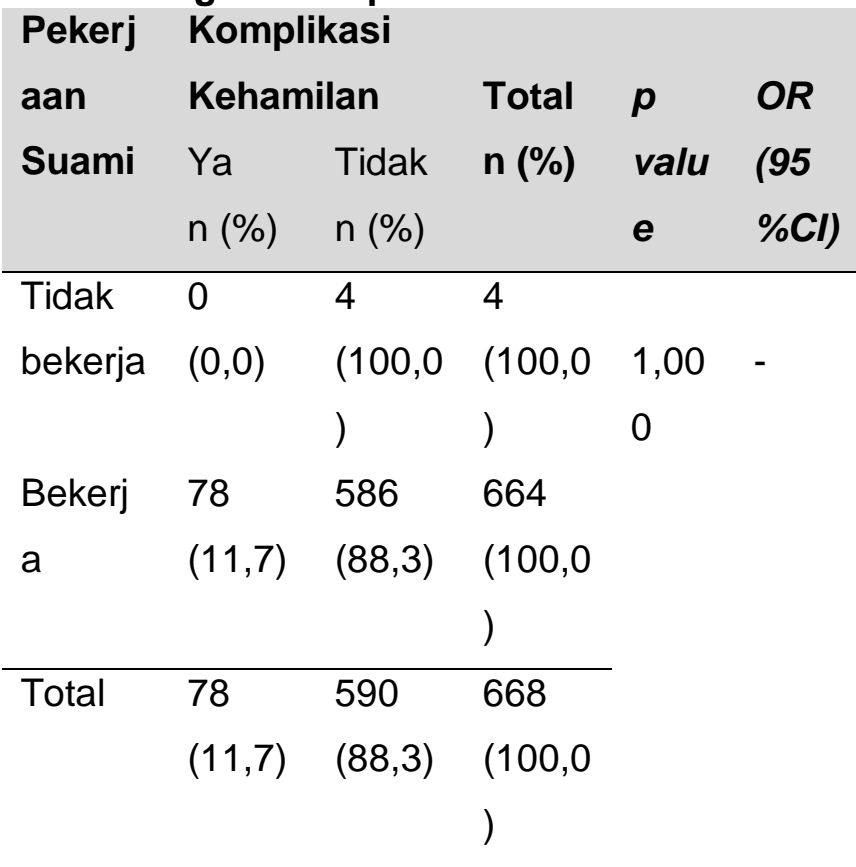

\section{Hubungan Paritas dengan Komplikasi Kehamilan}

Hasil analisis hubungan paritas dengan komplikasi kehamilan didapatkan bahwa dari 95 Ibu mempunyai paritas resiko tinggi yang mengalami komplikasi kehamilan sebanyak 47 orang $(49,5 \%)$ sedangkan Ibu dengan paritas resiko rendah sebanyak 31 orang (5,4\%) dari 573 orang. Hasil uji chi square, diperoleh nilai signifikan $p=0,000$ ( $p$ value $<$ 0,05). Hal ini menunjukkan bahwa Ho ditolak, Ha diterima sehingga dapat disimpulkan ada hubungan antara paritas dengan komplikasi kehamilan.
Tabel 5. Hubungan Paritas dengan Komplikasi Kehamilan

\begin{tabular}{|c|c|c|c|c|c|}
\hline \multirow[t]{6}{*}{ Paritas } & \multicolumn{5}{|c|}{ Komplikasi } \\
\hline & \multicolumn{2}{|c|}{ Kehamilan } & \multirow{5}{*}{$\begin{array}{l}\text { Total } \\
\text { n (\%) }\end{array}$} & \multirow{5}{*}{$\begin{array}{l}p \\
\text { valu } \\
e\end{array}$} & \multirow{5}{*}{$\begin{array}{l}\text { OR } \\
(95 \% \\
\text { CI) }\end{array}$} \\
\hline & $\mathrm{Ya}$ & Tida & & & \\
\hline & $n$ & k & & & \\
\hline & $(\%)$ & $\mathrm{n}$ & & & \\
\hline & & $(\%)$ & & & \\
\hline Resiko & 47 & 48 & 95 & & 17,12 \\
\hline \multirow[t]{2}{*}{ tinggi } & $(49$ & $(50$ & $(100,0$ & 0,00 & 0 \\
\hline & 5) & 5) & ) & 0 & $(9,966$ \\
\hline Resiko & 31 & 542 & 573 & & - \\
\hline Renda & $(5,4)$ & (94, & $(100,0$ & & 29,40 \\
\hline h & & 6) & ) & & 9) \\
\hline \multirow[t]{3}{*}{ Total } & 78 & 590 & 668 & & \\
\hline & $(11$ & (88, & $(100,0$ & & \\
\hline & 7) & 3) & ) & & \\
\hline
\end{tabular}

\section{Hubungan Jarak Kehamilan dengan Komplikasi Kehamilan}

Hasil analisis hubungan jarak kehamilan dengan komplikasi kehamilan didapatkan bahwa dari 75 lbu yang mempunyia resiko tinggi yang mengalami komplikasi kehamilan sebanyak 10 orang (13,3\%) sedangkan lbu dengan jarak resiko rendah sebanyak 68orang $(11,5 \%)$ dari 593 orang. Hasil uji chi square, diperoleh nilai signifikan $p=0,777$ ( $p$ value $>0,05)$. Hal ini menunjukkan bahwa Ho diterima, $\mathrm{Ha}$ ditolak sehingga dapat disimpulkan tidak ada hubungan antara jarak kehamilan dengan komplikasi kehamilan. 


\begin{tabular}{|c|c|c|c|c|c|}
\hline \multirow{2}{*}{$\begin{array}{l}\text { Jarak } \\
\text { Keha } \\
\text { milan }\end{array}$} & \multicolumn{2}{|c|}{$\begin{array}{l}\text { Komplikasi } \\
\text { Kehamilan }\end{array}$} & \multirow{2}{*}{$\begin{array}{l}\text { Total } \\
\text { n (\%) }\end{array}$} & \multirow{2}{*}{$\begin{array}{l}p \\
\text { valu } \\
e\end{array}$} & \multirow{2}{*}{$\begin{array}{l}\text { OR } \\
(95 \% C \\
\text { l) }\end{array}$} \\
\hline & $\begin{array}{l}\text { Ya } \\
\text { n (\%) }\end{array}$ & $\begin{array}{l}\text { Tidak } \\
\text { n (\%) }\end{array}$ & & & \\
\hline $\begin{array}{l}\text { Resiko } \\
\text { tinggi }\end{array}$ & $\begin{array}{l}10 \\
(13,3)\end{array}$ & $\begin{array}{l}65 \\
(86,7 \\
)\end{array}$ & $\begin{array}{l}75 \\
(100,0)\end{array}$ & $\begin{array}{l}0,77 \\
7\end{array}$ & $\begin{array}{l}1,188 \\
(0,583 \\
2,421)\end{array}$ \\
\hline $\begin{array}{l}\text { Resiko } \\
\text { Renda } \\
\text { h }\end{array}$ & $\begin{array}{l}68 \\
(11,5)\end{array}$ & $\begin{array}{l}525 \\
(88,5 \\
)\end{array}$ & $\begin{array}{l}593 \\
(100,0)\end{array}$ & & \\
\hline Total & $\begin{array}{l}78 \\
(11,7)\end{array}$ & $\begin{array}{l}590 \\
(88,3 \\
)\end{array}$ & $\begin{array}{l}668 \\
(100,0)\end{array}$ & & \\
\hline
\end{tabular}

\section{Hubungan Riwayat Abortus dengan Komplikasi Kehamilan}

Hasil analisis hubungan riwayat abortus dengan komplikasi kehamilan didapatkan bahwa dari 95 lbu dengan riwayat abortus yang mengalami komplikasi kehamilan sebanyak 63 orang (100\%) sedangkan lbu yang tidak pernah mengalami abortus sebanyak 15 orang (2,5\%) dari 593 orang. Hasil uji chi square, diperoleh nilai signifikan $p=0,777(p$ value $<0,05)$. Hal ini menunjukkan bahwa Ho ditolak, Ha diterima sehingga dapat disimpulkan ada hubungan antara riwayat abortus dengan komplikasi kehamilan.
Tabel 7. Hubungan Riwayat Abortus dengan Komplikasi Kehamilan

\section{Riway Komplikasi}

\begin{tabular}{llllll} 
at & \multicolumn{2}{l}{ Kehamilan } & Total & $\boldsymbol{p}$ & OR \\
Abort & Ya & Tidak & $\mathrm{n}(\%)$ & valu & $(95 \%$ Cl) \\
us & $\mathrm{n}(\%)$ & $\mathrm{n}(\%)$ & & $\boldsymbol{e}$ & \\
\cline { 1 - 4 } Ada & 63 & $0(0,0)$ & 95 & & \\
& $(100,0)$ & & $(100,0)$ & 0,00 & - \\
Tidak & 15 & 590 & 573 & 0 & \\
ada & $(2,5)$ & $(97,5)$ & $(100,0)$ & & \\
\hline Total & 78 & 590 & 668 & & \\
& $(11,7)$ & $(88,3)$ & $(100,0)$ & &
\end{tabular}

\section{Hubungan Kunjungan ANC dengan Komplikasi Kehamilan}

Hasil analisis hubungan kunjuangan ANC dengan komplikasi kehamilan didapatkan bahwa dari 520 lbu dengan riwayat tinggi yang mengalami komplikasi kehamilan sebanyak 62 orang (11,9\%) sedangkan lbu dengan resiko rendah sebanyak 16 orang $(10,8 \%)$ dari 148 orang. Hasil uji chi square, diperoleh nilai signifikan $p=0,821$ ( $p$ value > 0,05). Hal ini menunjukkan bahwa Ho diterima, $\mathrm{Ha}$ ditolak sehingga dapat disimpulkan tidak ada hubungan antara kunjungan ANC dengan komplikasi kehamilan. 
Tabel 8. Hubungan Kunjungan ANC dengan Komplikasi Kehamilan

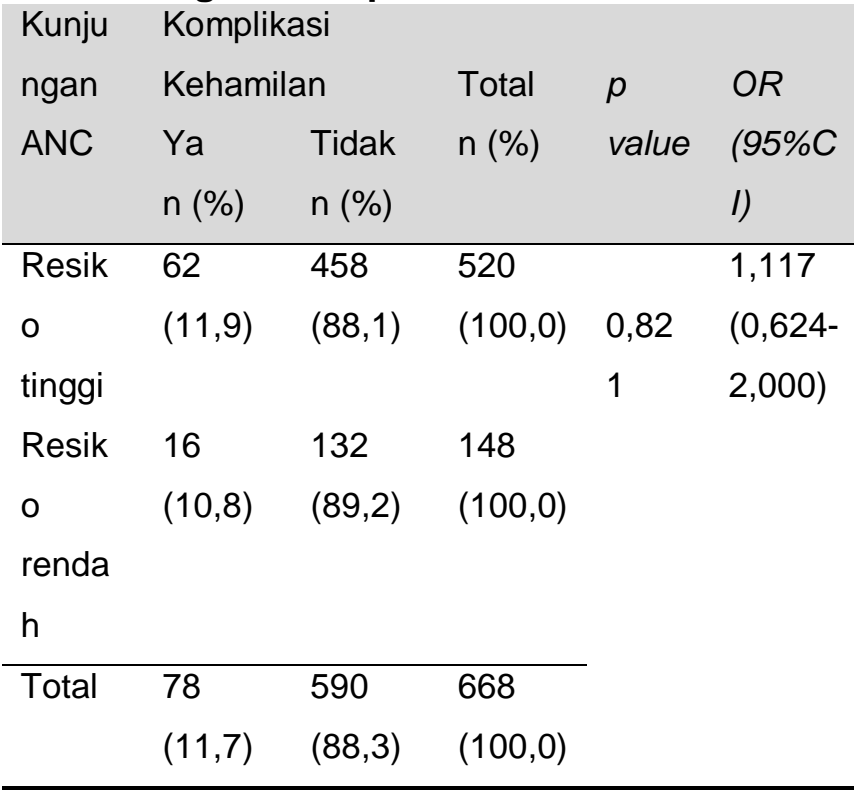

\section{Analisis Multivariat}

Analisis multivriat untuk mengetahui variabel yang paling dominan dalam mempengaruhi komplikasi kehamilan. Pada penelitian ini variabel yang diduga berhubungan dengan komplikasi kehamilan yaitu : umur, pendidikan, pekerjaan lbu, Pekerjaan suami, paritas dan jarak kehamilan, riwayat abortus dan kunjungan ANC. Berdasarkan hasil analisis bivariat variable yang masuk dalam kandidat analisis multivariat yaitu, pekerjaan Ibu, paritas dan riwayat abortus. Analisis multivariat menggunakan uji regresi logistik binare dengan metode enter, sehingga didapatkan model regresi logistik sebagai berikut:
Tabel 9. Model Regresi Logistik Metode Enter

\begin{tabular}{llllll} 
Variabel & Koefi & $\boldsymbol{p}$ & Exp & \multicolumn{2}{l}{$\mathbf{9 5 \%}$ Cl } \\
& sien & $\begin{array}{l}\text { value } \\
\text { (Sig.) }\end{array}$ & (B) & $\begin{array}{l}\text { Low } \\
\text { er }\end{array}$ & Upp \\
& & er \\
\hline Paritas & \multirow{2}{*}{$-2,840$} & 0,000 & 0,05 & 0,03 & 0,10 \\
& & & 8 & 4 & 0 \\
\hline
\end{tabular}

Constant

$=2,819$

\section{PEMBAHASAN}

1. Hubungan Usia dengan Komplikasi Kehamilan

Hasil analisis hubungan usia dengan komplikasi kehamilan didapatkan bahwa dari 130 lbu yang berusia resiko tinggi $(<20-\geq 35$ tahun) yang mengalami komplikasi kehamilan sebanyak 16 orang (12,3\%) sedangkan lbu yang berusia resiko rendah (20-35 tahun) sebanyak 62 orang $(11,5 \%)$ dari 538 orang. Hasil uji chi square, diperoleh nilai signifikan $\mathrm{p}=0,922(p$ value $>0,05)$. Hal ini menunjukkan bahwa Ho diterima, Ha ditolak sehingga dapat disimpulkan tidak ada hubungan antara usia ibu dengan komplikasi kehamilan.

Sejalan dengan penelitian Ari Murdiati, Sutopo Patria Jati (2017) yang berjudul Analisis Faktor- Faktor Yang Berhubungan dengan Perilaku Ibu Hamil dalam Merencanakan Persalinan Untuk Pencegahan komplikasi di Wilayah Kerja Puskesmas Bandarharjo Kota Semarang . Hasil: analisis univariat menunjukkan bahwa sebanyak $61,1 \%$ ibu hamil berada pada usia kehamilan yang tidak berisiko. Hasil analisis 
bivariat menunjukkan tidak ada hubungan antara umur ibu hamil dalam perencanaan persalinan untuk pencegahan komplikasi $p$ value $=0,310>0,05$.

Menurut Green (2000) bahwa umur merupakan faktor demografi yang tidak berpengaruh secara langsung terhadap perilaku ${ }^{(8)}$

Menurut peneliti tidak ada hubungan antara umur ibu hamil dalam upaya pencegahan komplikasi kehamilan antara ibu hamil yang usia berisiko dengan usia yang tidak berisiko karena dalam mendapatkan informasi tentang upaya pencegahan komplikasi kehamilan adalah sama yaitu dari tenaga pelayanan kesehatan, internet, televisi, majalah, koran, radio.

2. Hubungan Pendidikan ibu dengan Komplikasi Kehamilan

Hasil analisis hubungan pendidikan lbu dengan komplikasi kehamilan didapatkan bahwa dari 174 lbu yang berpendidikan rendah yang mengalami komplikasi kehamilan sebanyak 21 orang (12,1\%) sedangkan Ibu yang berpendidikan tinggi sebanyak 57 orang $(11,5 \%)$ dari 494 orang. Hasil uji chi square, diperoleh nilai signifikan $\mathrm{p}=0,960 \quad(p$ value $>0,05)$. Hal ini menunjukkan bahwa Ho diterima, Ha ditolak sehingga dapat disimpulkan tidak ada hubungan antara pendidikan ibu dengan komplikasi kehamilan.

Sejalan dengan penelitian Ari Murdiati, Sutopo Patria Jati (2017) yang berjudul Analisis Faktor- Faktor Yang Berhubungan dengan Perilaku lbu Hamil dalam
Merencanakan Persalinan Untuk

Pencegahan komplikasi di Wilayah Kerja Puskesmas Bandarharjo Kota Semarang. Hasil: analisis univariat menunjukkan bahwa sebanyak $55,6 \%$ ibu hamil berpendidikan menengah. Hasil analisis bivariat menunjukkan tidak ada hubungan antara pendidikan ibu hamil dengan perilaku ibu hamil dalam perencanaan persalinan untuk pencegahan komplikasi ( $p$ - value: 1,000 > $0,05)$

Tidak adanya hubungan antara pendidikan ibu hamil dengan perilaku ibu hamil dalam perencanaan persalinan untuk pencegahan komplikasi kehamilan ini didukung oleh teori perilaku yang menyatakan bahwa hasil pendidikan adalah perubahan kemampuan pelakunya, selanjutnya perubahan perilaku didasari adanya perubahan atau penambahan pengetahuan, sikap atau keterampilannya. Tetapi perubahan pengetahuan dan sikap bukan merupakan jaminan perubahan perilaku sebab perilaku tersebut kadang-kadang memerlukan material (Jalaluddin, 2012) ${ }^{(9)}$.

3. Hubungan Pekerjaan lbu dengan Komplikasi Kehamilan

Hasil analisis hubungan pekerjaan Ibu dengan komplikasi kehamilan didapatkan bahwa dari 509 lbu yang tidak bekerja yang mengalami komplikasi kehamilan sebanyak 68 orang $(13,4 \%)$ sedangkan lbu yang bekerja sebanyak 10 orang $(6,3 \%)$ dari 159 orang. Hasil uji chi square, diperoleh nilai signifikan $p=0,022(p$ value $<0,05)$. Hal ini menunjukkan bahwa Ho ditolak, Ha diterima 
sehingga dapat disimpulkan ada hubungan antara pekerjaan ibu dengan komplikasi kehamilan.

Penelitian ini berbeda dengan penelitian Ari Murdiati, Sutopo Patria Jati (2017) yang berjudul Analisis FaktorFaktor Yang Berhubungan dengan Perilaku lbu Hamil dalam Merencanakan Persalinan Untuk Pencegahan komplikasi di Wilayah Kerja Puskesmas Bandarharjo Kota Semarang. Hasil analisis univariat menunjukkan bahwa sebanyak $60 \%$ ibu hamil bekerja. Hasil analisis bivariat menunjukkan tidak ada hubungan antara pekerjaan ibu hamil dengan perilaku ibu hamil dalam perencanaan persalinan untuk pencegahan komplikasi kehamilan ( $p$-value $0,399>0,05)$.

Menurut teori perilaku Green (2000) pekerjaan bukan merupakan faktor yang berpengaruh secara langsung terhadap perubahan perilaku.

4. Hubungan Pekerjaan Suami dengan Komplikasi Kehamilan

Hasil analisis hubungan pekerjaan Suami dengan komplikasi kehamilan didapatkan bahwa dari 4 suami yang tidak bekerja yang istrinya mengalami komplikasi kehamilan sebanyak 0 orang $(0 \%)$ sedangkan suami yang bekerja sebanyak 78 orang $(11,7 \%)$ dari 664 orang. Hasil uji chi square, diperoleh nilai signifikan $p=1,000$ ( $p$ value $>0,05)$. Hal ini menunjukkan bahwa $\mathrm{Ho}$ diterima, $\mathrm{Ha}$ ditolak sehingga dapat disimpulkan tidak ada hubungan antara pekerjaan suami dengan komplikasi kehamilan.

Sejalan dengan penelitian Desri Magdalena Purba, Asri, Adisasmita yang berjudul Faktor- Faktor Yang Berhubungan Dengan Kejadian Komplikasi Kehamilan dan Persalinan Di Rumah Sakit Umum Daerah (RSUD) Kota Depok Tahun 2012. Penelitian ini menunjukkan tidak ada hubungan antara status bekerja suami dengan kejadian komplikasi kehamilan $p$ value $0,705^{(10)}$.

Pekerjaan suami menunjukkan status keluarga di masyarakat (Royston dan Amstrong, 1989) (11).

5. Hubungan Paritas dengan Komplikasi Kehamilan

Hasil analisis hubungan paritas dengan komplikasi kehamilan didapatkan bahwa dari 95 Ibu mempunyai paritas resiko tinggi yang mengalami komplikasi kehamilan sebanyak 47 orang (49,5\%) sedangkan lbu dengan paritas resiko rendah sebanyak 31 orang $(5,4 \%)$ dari 573 orang. Hasil uji chi square, diperoleh nilai signifikan $p=0,000$ ( $p$ value $<0,05)$. $\mathrm{Hal}$ ini menunjukkan bahwa $\mathrm{Ho}$ ditolak, $\mathrm{Ha}$ diterima sehingga dapat disimpulkan ada hubungan antara paritas dengan komplikasi kehamilan.

Sejalan dengan penelitian Ari Murdiati, Sutopo Patria Jati (2017) yang berjudul Analisis Faktor- Faktor Yang Berhubungan dengan Perilaku Ibu Hamil dalam Merencanakan Persalinan Untuk Pencegahan komplikasi di Wilayah Kerja 
Puskesmas Bandarharjo Kota Semarang . Hasil univariat menunjukkan bahwa sebanyak $56,7 \%$ ibu hamil pernah melahirkan. Hasil analisis bivariat menunjukkan ada hubungan antara paritas ibu hamil dengan perilaku ibu hamil dalam perencanaan persalinan untuk pencegahan komplikasi $p$ value 0,011 0,05.

Paritas kaitannya dengan perilaku ibu hamil dalam perencanaan persalinan untuk pencegahan komplikasi kehamilan tidak terlepas dari apa yang disebut dengan pengalaman. Untuk memperoleh pengalaman ada empat cara tradisional yang digunakan. Pertama adalah cara coba-coba (trial and error), cara ini dilakukan dengan mencobacoba, jika gagal akan diulang-ulang hingga berhasil. Kedua adalah cara kekuasaan atau otoritas, pada cara ini pengetahuan didapatkan dari orang yang berpengaruh dalam masyarakat lalu diikuti tanpa rasionalisasi. Ketiga adalah berdasarkan pengalaman pribadi, dimana pengalaman seseorang akan memberi pengetahuan baru pada orang tersebut. Ke empat adalah melalui jalan pikiran maksudnya pengetahuan diperoleh seseorang dengan penalaran dan membuat kesimpulan (Notoadmodjo, 2010) (12).

6. Hubungan Jarak Kehamilan dengan Komplikasi Kehamilan

Hasil analisis hubungan jarak kehamilan dengan komplikasi kehamilan didapatkan bahwa dari 75 lbu yang mempunyia resiko tinggi yang mengalami komplikasi kehamilan sebanyak 10 orang (13,3\%) sedangkan lbu dengan jarak resiko rendah sebanyak 68orang $(11,5 \%)$ dari 593 orang. Hasil uji chi square, diperoleh nilai signifikan $p=0,777$ ( $p$ value $>0,05)$. Hal ini menunjukkan bahwa Ho diterima, $\mathrm{Ha}$ ditolak sehingga dapat disimpulkan tidak ada hubungan antara jarak kehamilan dengan komplikasi kehamilan.

Sejalan dengan penelitian Desri Magdalena Purba, Asri, Adisasmita yang berjudul Faktor- Faktor Yang Berhubungan Dengan Kejadian Komplikasi Kehamilan dan Persalinan Di Rumah Sakit Umum Daerah (RSUD) Kota Depok Tahun 2012. Hasil tidak ada hubungan antara jarak lahir dengan komplikasi kehamilan nilai $p$ value 1,000.

7. Hubungan Riwayat Abortus dengan Komplikasi Kehamilan

Hasil analisis hubungan riwayat abortus dengan komplikasi kehamilan didapatkan bahwa dari 95 lbu dengan riwayat abortus yang mengalami komplikasi kehamilan sebanyak 63 orang (100\%) sedangkan lbu yang tidak pernah mengalami abortus sebanyak 15 orang $(2,5 \%)$ dari 593 orang. Hasil uji chi square, diperoleh nilai signifikan $\mathrm{p}=0,777(\mathrm{p}$ value $<0,05)$. Hal ini menunjukkan bahwa Ho ditolak, Ha diterima sehingga dapat disimpulkan ada hubungan antara riwayat abortus dengan komplikasi kehamilan.

Penelitian ini berbeda dengan penelitian Desri Magdalena Purba, Asri, Adisasmita yang berjudul Faktor- Faktor Yang Berhubungan Dengan Kejadian Komplikasi Kehamilan dan Persalinan Di Rumah Sakit Umum Daerah (RSUD) Kota Depok Tahun 2012. Hasil tidak ada hubungan antara 
riwayat abortus dengan kejadian komplikasi kehamilan $p$ value 0,238 .

Menurut Manuaba (1999) yang mengemukakan bahwa riwayat kehamilan yang buruk seperti abortus dan kehamilan ektopik dapat memberi dampak buruk bagi kehamilan dan persalinan ibu saat ini. Jika ibu mengalami abortus terutama abortus yang dilakukan secara sengaja akan membawa dampak buruk bagi kesehatan ibu (13). Adapun bahaya yang dapat terjadi karena abortus antara lain adalah terjadinya komplikasi kehamilan dan persalinan berupa perdarahan yang hebat, kerusakan servik, infeksi yang dapat menyebabkan kemandulan, syok (Sastrawinata, 2003) (14).

8. Hubungan Kunjungan ANC dengan Komplikasi Kehamilan

Hasil analisis hubungan kunjuangan ANC dengan komplikasi kehamilan didapatkan bahwa dari 520 lbu dengan riwayat tinggi yang mengalami komplikasi kehamilan sebanyak 62 orang (11,9\%) sedangkan lbu dengan resiko rendah sebanyak 16 orang $(10,8 \%)$ dari 148 orang. Hasil uji chi square, diperoleh nilai signifikan $\mathrm{p}=0,821$ ( $p$ value $>0,05)$. Hal ini menunjukkan bahwa Ho diterima, Ha ditolak sehingga dapat disimpulkan tidak ada hubungan antara kunjungan ANC dengan komplikasi kehamilan.

Penelitian ini berbeda dengan penelitian Desri Magdalena Purba, Asri, Adisasmita yang berjudul Faktor- Faktor Yang Berhubungan Dengan Kejadian Komplikasi Kehamilan dan Persalinan Di Rumah Sakit
Umum Daerah (RSUD) Kota Depok Tahun 2012. Hasil ada hubungan antara jumlah kunjungan ANC dengan kejadian komplikasi kehamilan. Kunjungan ANC $<4$ kali $p$ value 0,015 dan kunjungan $\mathrm{ANC} \geq 4$ kali $p$ value 0,087 .

\section{SIMPULAN DAN SARAN}

\section{Simpulan}

Berdasarkan hasil penelitian yang telah dilakukan di BPM Ellna sebanyak 668 reponden dapat disimpulkan sebagai berikut:

1. Tidak ada hubungan antara usia ibu dengan komplikasi kehamilan. Hasil uji chi square, diperoleh nilai signifikan $\mathrm{p}=$ $0,922$ ( $p$ value $>0,05)$.

2. Tidak ada hubungan antara pendidikan ibu dengan komplikasi kehamilan. Hasil uji chi square, diperoleh nilai signifikan $p=0,960(p$ value $>0,05)$

3. Ada hubungan antara pekerjaan ibu dengan komplikasi kehamilan. Hasil uji chi square, diperoleh nilai signifikan $p=$ $0,022$ ( $p$ value $<0,05)$.

4. Tidak ada hubungan antara pekerjaan suami dengan komplikasi kehamilan. Hasil uji chi square, diperoleh nilai signifikan $p=1,000$ ( $p$ value $>0,05$ ).

5. Ada hubungan antara paritas dengan komplikasi kehamilan. Hasil uji chi square, diperoleh nilai signifikan $\mathrm{p}=$ $0,000$ ( $p$ value $<0,05)$.

6. Tidak ada hubungan antara jarak kehamilan dengan komplikasi kehamilan. Hasil uji chi square, diperoleh nilai signifikan $\mathrm{p}=0,777(p$ 
value $>0,05)$.

7. Ada hubungan antara riwayat abortus dengan komplikasi kehamilan. Hasil uji chi square, diperoleh nilai signifikan $\mathrm{p}=$ $0,777$ ( $p$ value $<0,05)$.

8. Tidak ada hubungan antara kunjungan ANC dengan komplikasi kehamilan. Hasil uji chi square, diperoleh nilai signifikan $p=0,821$ ( $p$ value $>0,05$ ).

\section{Saran}

1. Bagi Ibu Hamil

Diharapkan bagi ibu hamil lebih banyak mengetahui upaya pencegahan komplikasi kehamilan.

2. Bagi BPM Ellna

Diharapkan dapat menjadi sumber informasi bagi BPM Ellna Palembang dalam upaya meningkatkan pelayanan kesehatan pada ibu hamil.

\section{DAFTAR PUSTAKA}

1. WHO. (2014). Maternal Mortality. Diakses pada tanggal 18 Maret 2018 di http://www.who.int/mediacentre/factshe ets/fs348/en/

2. Profil Seksi Kesehatan Keluarga dan Gizi Masyarakat. (2017). Pencapaian dan Kinerja Pembangunan Kesehatan. Kota Palembang.

3. Murdiati Ari, Jati Patria Sutopo. (2017). Analisis Faktor-Faktor Yang Berhubungan dengan Perilaku Ibu Hamil Dalam Merencanakan Persalinan untuk Pencegahan Komplikasi di Wilayah Kerja Puskesmas Bandar Harjo Semarang. Jurnal Promosi Kesehatan Indonesia vol. 12/ no. I/ Januari. Akbid Abdi Husada Semarang. Tesis. Semarang. Universitas Diponegoro Semarang.

4. Ika Tristanti, Nasriyah. (2016). Upaya pencegahan Komplikasi Kehamilan dan
Persalinan Berdasarkan Karakteristik Ibu Hamil di Kabupaten Kudus. Skripsi. Kudus: STIKES Muhammadiyah Kudus.

5. Mulyadi, Werdiyanthi, Karundeng Michael. (2017). Hubungan penerapan Program Perencanaan Persalinan dan Pencegahan Komplikasi Kehamilan oleh lbu Hamil Dengan Komplikasi Kehamilan di Puskesmas Doloduo Kabupaten Bolaang Mongondow. Program Studi IImu Keperawatan Fakultas Kedokteran Universitas Sam Ratulangi.

6. Data Rekam Medik. (2017). BPM Ellna Kota Palembang.

7. Arikunto, Suharsini (2010). Prosedur Penelitian Suatu Pendekatan Praktek. Jakarta. Rineka Cipta.

8. Green W Lawrence, Kreuter W Marshall. (2000). Health Promotion Planning: an

Educational and Environmental Approach Second Edition. Mayfield Publishing Company California.

9. Jalaludin. R. (2012). Psikologi Komunikasi. PT Remaja Rosdakarya Bandung.

10. Purba Magdalena Desri. Asri. Adisasmita. (2013). Faktor- Faktor Yang Berhubungan Dengan Kejadian Komplikasi Kehamilan Dan persalinan Di Rumah Sakit Umum Daerah (RSUD) Kota Depok. Program Studi Kesehatan Masyarakat. Fakultas Kesehatan Masyarakat.

11. Royston, Erica., \& Amstrong, Sue., (1989). Preventing Maternal Death. World Health Organization (WHO).

12. Notoatmojo. S. (2002). Metode Penelitian Kesehatan. Jakarta.

13. Manuaba. 2015. Buku Ajar Asuhan Persalinan Normal. Yogyakarta: Nuha Medika.

14. Sastra winata et al. (2003). IImu Kesehatan Reproduksi Obstetri Patologi. Buku Kedokteran 